\title{
"Irish English had to do with personal identity, and you can't get rid of that". An Interview with Juan José Delaney
}

\author{
Carolina P. Amador-Moreno \\ University of Extremadura, Spain
}

Copyright (c) 2018 by Carolina P. Amador-Moreno. This text may be archived and redistributed both in electronic form and in hard copy, provided that the author and journal are properly cited and no fee is charged for access.

\begin{abstract}
In this interview, Irish-Argentine writer Juan José Delaney reflects upon his writing. His own cultural affiliation with both the Irish and the Argentinian culture come to the fore in his answers. Thus, when asked about his background he replies: "I have always been nourished by both the Argentinian and the Irish cultures". Juan José Delaney was born in Buenos Aires in 1954. He is a fiction writer and essayist and he holds the chair in Twentieth Century Argentinean Literature at the Universidad del Salvador (Buenos Aires), where he also coordinates the Irish Studies Program. As a fiction writer, he has published the collections Papeles del Desierto (1974-2004), and Tréboles del Sur (1994), which has been recently reedited (2014). His novel, Moira Sullivan (1999), like many of his short stories, depicts the life of the Irish in Argentina, a topic that he returns to in his most recent nouvelle, Memoria de Theophilus Flynn (2012), which connects Waterford with Buenos Aires. He is also the author of a dramatic comedy entitled La viuda de O'Malley and the biography Marco Denevi y la sacra ceremonia de la escritura (2006). During the course of the interview he discusses cultural and linguistic assimilation issues that were conspicuous in the context of Irish emigration to Argentina.
\end{abstract}

Key Words. Irish Emigration, Argentina, Hybridity, Irish-English / Hiberno-English, IrishPorteño Speech.

Resumen. En esta entrevista el escritor hiberno-argentino Juan José Delaney reflexiona sobre su obra. Tanto la cultura argentina como la irlandesa, piedras angulares de su identidad cultural, salen a relucir en la conversación. A la pregunta acerca de su origen, por ejemplo, responde: "Siempre me he nutrido de las culturas argentina e irlandesa". Juan José Delaney nació en Buenos Aires en 1954. Además de ser un escritor de ficción y ensayista, dirige la cátedra de Literatura Argentina del Siglo XX en la Universidad del Salvador (Buenos Aires), donde también coordina el programa de Estudios Irlandeses. Como escritor de ficción, ha firmado las colecciones Papeles del Desierto (1974-2004) y Tréboles del Sur (1994), recientemente reeditada (2014). Su novela Moira Sullivan (1999), al igual que muchos de sus relatos, describe la vida de los irlandeses en Argentina, un tema al que acude de nuevo en su novela corta Memoria de Theophilus Flynn (2012), en la que se relaciona a Waterford con Buenos Aires. Es también autor de la comedia dramática La viuda de O’Malley, así como de 
la biografía Marco Denevi y la sacra ceremonia de la escritura (2006). A lo largo de esta entrevista se discuten temas relacionados con la asimilación lingüística y cultural que son relevantes en el contexto de la emigración irlandesa a Argentina.

Palabras clave. Emigración irlandesa, Argentina, hibridación cultural, inglés de Irlanda / hiberno-inglés, habla hiberno-porteña

Walking around the streets of Buenos Aires one discovers many Irish connections, whether looking for them or not: there is the Parroquia San Patricio, el Hurling Club, el colegio Santa Brígida, and there are neighbourhoods, streets and train stations that carry the names of Irishmen who left their mark in the country: el almirante William "Guillermo" Brown, Juan Coghlan, Patrick Sarsfield, etc. The photographs and memorabilia preserved in the old Hotel of Immigrants, now the Museum of Immigration, bear the testimony of other less known Irish emigrants who settled in this country and also contributed in a smaller way to the (intra)history of Argentina. Juan José Delaney (Buenos Aires, 1954) has fictionalised the lives and stories of those immigrants. With Tréboles del sur (1994), he won the Third Municipal Literature Prize of the City of Buenos Aires, Moira Sullivan (1999) and the nouvelle Memoria de Theophilus Flynn (2012) and the play La viuda de O'Malley, followed later.

\section{Carolina P. Amador-Moreno: You're a writer of Irish descent. Would you say that your own artistic inspiration comes from that Irish-Argentine background?}

Juan José Delaney: When I was doing my secondary school I discovered the short story, and little by little I started collecting books... that was the beginning of my private library: Oscar Wilde, Edgar Allan Poe, Horacio Quiroga and Jorge Luis Borges were my first friends. It was a secret collection because I was a boarder in a Salesian school and Borges was banned because he was considered a "destructor" and a "nihilist". The thing was that, as a reaction, the author of El Aleph became my idol and together with the other writers, a model when, at 15, I decided that I wanted to write short stories and become a writer. Two years after that I saw my first story published in The Southern Cross, the Irish-Porteño newspaper. It was called "Los dos sueños", it had nothing to do with the Irish and it was clearly influenced by Borges's works. My second story published by The Southern Cross was called "Los papeles de Nicholas Coughlan" and this time, yes, I paid tribute to my ancestors. Although I wrote and still write essays and fiction that doesn't refer to the Irish migration to the River Plate, this is recurrent in my writing because it's the topic I know best.

\section{CAM: In what way would you say Irish-Argentinian writers of fiction have contributed to the overall literary scene of Argentina?}

It's not easy to give an answer to this question since two of the three principal Irish or IrishArgentine writers wrote their works in Irish English. I'm referring to William Bulfin and his Tales of the Pampas (1900) and Kathleen and Winnie Nevin and their novel You'll Never Go Back (1946). These works are important in two senses: they give an account of the Irish contribution to that South American melting pot which is Argentina, and they are significant linguistic documents of the slow process of integration and adaptation of the Irish and their descendants to the host country as well. Both books were translated into Spanish with no impact, since the essence of their value is in language, in the way characters speak English (or Irish English) and the way they try to include Spanish words in their speech. 
Rodolfo Walsh is a different story. He wrote all his work in Spanish and his texts are seen as a model in terms of style. Critics have noted his masterly use of the resource known as ellipsis. It happens to me that while I'm reading his texts I feel that there is something else hinted or suggested by the narrator, that he is telling a story and at the same time another (the principal one) that is unseen. I feel that this comes from the English he learned at home and with the Pallotines in the Fahy Farm, an English variation influenced by the Irish language where ellipsis plays a considerable role. At present I'm working in an essay trying to prove this. Walsh is considered one of the four best short story writers in Argentina, together with Jorge Luis Borges, Julio Cortázar and Marco Denevi.

CAM: I've heard authors like Hugo Hamilton talk about the hybridised self-image that complicated his cultural affiliation. Was that your case too?

JJD: Although I went through that same experience, I never felt that it complicated my cultural affiliation. Perhaps the fact that I didn't do my schooling in Irish institutions had much to do with my bi-cultural formation. I have always been nourished by both the Argentinian and the Irish cultures. My position today at the University reveals that: I teach Argentine Literature and I also coordinate the Irish Studies Program. So, there is no conflict but a mutual benefit.

CAM: Hybrid identities sometimes give way to the desire to fit in. As a writer, you use your name Juan José Delaney, which shows that hybridity. Were you ever tempted to use any other pen-name(s) as a writer?

JJD: Yes, I was tempted to sign my books in a different way: J.J. Delaney, Jack Delaney... In 1993 I took part in the International Writing Program, at the University of Iowa, in the USA. I remember that one of the subjects discussed had to do with this question. And most of my colleagues concluded that, in my case, Juan José Delaney revealed the rich encounter of two cultures. So they convinced me that the best, realistic and honest thing to do was to sign my books with my real name.

CAM: You grew up in an English-speaking household, how easy was it to maintain English in a Spanish-speaking country?

JJD: From my childhood on, I was always an active member of the Irish-Argentine community in Buenos Aires. English (or Irish English) was the language we used to address old people; the next generation would speak that strange mixture called Irish-Porteño. Nowadays, Spanish (or Argentino) is the regular language spoken in Irish-Porteño meetings.

\section{CAM: Did you ever consider writing in English instead of Spanish?}

JJD: No. Although my first literary readings were in English, from the very beginning my personal project was to become a writer in Spanish, a language I love as much as English. For academic reasons, I wrote three books in English: my doctoral thesis on the Irish in Argentina, a sequel of my dissertation: Language and Literature of the Irish in Argentina, and a summary of papers I gave on Borges in different Universities: Borges and Irish Writing.

CAM: Yes, and you've just mentioned how Borges influenced your own writing. Tell us a bit more about Borges and Irish writing. 
Borges always had a special devotion for certain Irish writers. I met the man three times. The first one for the sake of thanking him for having praised my first collection of short stories. I remember that he immediately started speaking of the Irish writers, concluding with his classic statement that the best English writers were Irish. If you go through Borges's works you'll find that from the very beginning of his career Irish writers are there: Oscar Wilde, Bernard Shaw, Jonathan Swift, John Scotus Erigena, Yeats... not to speak of his ambivalent relationship with Joyce's works... even authors considered more or less marginal in Ireland as Laurence Sterne and George Moore... But the great Irish influence on Borges was George Berkeley's idealism philosophy. Together with that of Schopenhauer, the Irish Anglican Bishop's vision is central to Borges's writing.

CAM: That brings me to my next question, which has to do with his positive reaction to your writing. Was that important at that stage of your writing career?

JJD: No doubt. First of all, it was important because his opinion came at a moment when I was not sure what to do with my life, whether to study Law for the sake of certain security or Letters, a discipline that promised me an uncertain future... Borges's statement on my work and his advice in the sense that I should continue writing convinced me what I had to do, and that I was on the right track. At that time, he was, already, my hero.

CAM: Let's go back to the Irish Argentines you recreate in your writing. What are your memories of the former generations of Irish Argentines?

JJD: They always spoke English (or Irish English), they were very religious, they had a very good sense of humour, they loved Argentina, they hated Perón, they preferred living in the countryside and, basically, they were very good people.

CAM: Tell us a bit more about the language they used. You have just mentioned they spoke English (or Irish English), which, as you know, is a topic I am particularly interested in.

JJD: The Irish brogue was evident. Besides, they spoke an English language that admitted Spanish interpolations and even neologisms, such as: "camp" (from "campo"), instead of countryside, "convention" (from "conventillo") instead of boarding house. You would listen to expressions like: "I'm afraid the food won't alcanzar" or "Throw that into the basura"... changes that were revealing the slow process of assimilation of the Irish and their descendants into the Argentine community.

CAM: In your work, some of the characters hesitate as to whether they should communicate in English or Spanish, poor Charlie Mullins in "Primer Amor", others like Timothy in "El Fundador", or Theophilus Flynn himself make it their aim to learn Spanish although they never get to master it.

JJD: To master the Spanish language was, obviously, a social necessity but at the same time it showed an honest will to become part of Argentina. Irish English had to do with personal identity, and you can't get rid of that.

CAM: Some other characters, like "El professor O'Hara", Annette Fleming in "La vida imita al arte", etc. actually benefit from their knowledge of English. While in some other cases, the language barrier isolates the character (that's what happens to Moira Sullivan, 
living in a home for the elderly, and also part of the problem that Tessie has, in the short story "Destinos").

JJD: Many of the "losers" (as we called them) who failed in their aim of becoming estancieros or at least chacareros, went back to the city and became executives in American or British companies. It was very common that young boys belonging to poor Irish families after finishing their primary school at the Fahy Institute or at any other Irish institution started working as office boys and gradually progressed, thanks to the English language. Girls took advantage of their English teaching in schools or privately, not to speak of all those well paid bilingual secretaries in the great companies. In the end, the English language (a language that was not their own, after all) was a great benefit for the Irish migrants.

CAM: "Destinos" is one of my favourite short stories in your collection, probably because of the epistolary style, but also because of the numbing silence at the end. I suppose there must have been a lot of letters written from Argentina?

JJD: I suppose so. I can refer to my own family and say that correspondence with Irish relatives was frequent. My own collection proves it. At the same time, I remember having published an ad in The Southern Cross asking for this kind of documents. Silence was the answer I got.

CAM: In Memoria de Theophilus Flynn, one of the characters when she is about to die, all of a sudden, starts speaking Irish, much to the surprise of her family. What is your memory of that language?

JJD: I knew only one Irish speaker within the Irish-Argentine community: Michael Geraghty. He made a living out of his excellent command of the English and Irish languages. It seems that Irish disappeared after the first wave of Irish migrants to the River Plate. It was a useless language, and, in this anglophile country, what counted was the English language. Anyway, even today you can hear single Irish words threading through the Irish-Porteño speech. Musha! is a common one, but also Sláinte.

CAM: The Southern Cross, the Buenos Aires Herald, and The Standard are mentioned in your writing, what role did those newspapers have among the Irish community?

JJD: The Standard, founded by two Irishmen, was a commercial paper and meant nothing to the Irish community. The Irish used to buy the Herald on Sundays for the sake of peeping at the British community, or because they were looking for a job or wishing to read good English. The Southern Cross was central to the development of the cultural, religious and social life of the Irish-Argentines during many, many years, from its foundation in 1875 . When I was preparing my work on the Irish in Argentina, I interviewed the elders at St. Patrick's Home; most of them had lived in the camp and there was a coincidence: every week they waited anxiously for the Southern Cross, "it was a kind of a Bible at home", as one of them said. "We used to fight to see who would be the first in reading it". If you go through all the collection till the present, you'll find that the Southern Cross reveals the ups and downs of the process of integration, adaptation and assimilation of the Irish in Argentina.

CAM: What about the schools and institutions like the Irish Girls' Home, St. Brigid's School, the Fahy Farm, etc.? Were they really as strict as you depict them in your work? 
JJD: No doubt. None of the victims of that hard system would deny the strictness with which they were treated. The paradox is that many of them are, at the same time, thankful for the education they received. Rodolfo Walsh wrote four stories giving an account of his experience at the Fahy Farm. My father, who was his companion, promised that he would never send his children to the Fahy. So, for better or worse, I missed that traumatic experience. At St. Brigid's, the Sisters of Mercy, who hardly had mercy on their students, used to say to the girls: "The doors of hell are always open for you".

CAM: Your writing also has numerous priests, some of whom are not fully convinced of their vocation.

JJD: As in Ireland, many young boys were sent to the Minor Seminary and pressed to enter the priesthood. I had an uncle who was obliged to go off to the Passionist seminary in Vicente Casares when he was eleven. How can one have clear ideas on vocation at that early age?

CAM: In your writing there are recurrent place names like Venado Tuerto, Junín, San Antonio de Areco, etc. Why did so many Irish emigrants end up in the country?

JJD: The Catholic Church promoted that. They did it from the very beginning because the Irish were prepared to work in the countryside and there was plenty of work there, in the porteño camp. Father Anthony Fahy, the Irish Patriarch here, had been in New York and Chicago and saw the terrible living conditions of the Irish in their ghettos over there. He didn't want to see that in Buenos Aires City.

CAM: Your fiction seems to be very much influenced by cinema, we find references to it in Moira Sullivan, in Memoria de Theophilus Flynn, and also in many of the short stories that make up Tréboles del Sur. There's John Huston's Moby Dick, for example, and there's plenty of references to silent movies. Does the interaction between the two types of fiction allow for more creativity?

JJD: I love watching movies, that substitution of reality. Sometimes it happens that we get from the movies what life denies us. I enjoy playing with that confusion between fiction and reality.

CAM: Your fiction also brings us back to Joyce in a creative way; it often plays on elements from his writing or even his persona, and fabricates a story connected with the Irish author, thus furthering his own reach in a way. Is the short story "Una carta de Joyce" one of those small tributes to Joyce?

JJD: It is. At that time, I admired Joyce not only for his work but for his decision of sacrificing everything in order to devote his life to writing. Two curious things happened with this story. When it was published for the first time in the cultural section of El País newspaper, in Montevideo, the text was presented as an original letter by Joyce. Years after, the editor of the Buenos Aires Herald phoned me asking for a photocopy of Joyce's letter because he wanted to include it in an article he was writing.

CAM: The story of Frank Crinigan (Porota's grandfather in Memoria de Theophilus Flynn) is, in a sense, a continuation of "Eveline". I think Joyce would have loved the way you develop Frank's profile. Has Joyce been a strong influence in your own approach to short-story writing? 
JJD: Although I read and enjoyed Dubliners, A Portrait of the Artist as a Young Man is my favourite. At the time I wrote my first fictions, my model of what a short story was based on the writings of Edgar Allan Poe. Joyce, together with Chejov and Katherine Mansfield changed that mould, promoting a short story that stresses atmosphere, situations and characters, rather than a strong plot and an unexpected ending. But I was impressed by that story that appears in Dubliners, "Eveline". There is no explanation to her paralysis, her decision of not joining Frank who wanted to bring her off to Buenos Aires. I think that the reason is that, at that time, in Europe, Buenos Aires was seen (and probably was) a centre of prostitution. I imagined Frank's story in Buenos Aires after that sequence in the port of Dublin. It worked, it was functional to Memoria de Theophilus Flynn.

CAM: Are you more comfortable with the short story, then, than with the essay or the novel?

JJD: The short story is the form I prefer as a reader and as a writer. I don't think I would be able to create a strong character as you are supposed to do when you write a novel, but I find it easy to create situations and plots. And I do my best to find the proper words, avoiding a florid or baroque style. Synthesis and simplicity is what I look for in literature and in life.

CAM: Finally, to go back to the legacy of the Irish in Argentina, I'd like to end with a humorous note that I think perfectly encapsulates what I'd call the Irish-Porteño wit: James Curry would deserve a short story all to himself. Tell us a bit about the connexion between this invented (?) character and the famous sauce.

JJD: James Carrey or Jimmy Carrey (as he wanted to be called), is a fictional character. But the story seems to be real. Believe it or not, I heard it from a taxi driver who had nothing to do with the Irish. Then, when I polished the story and repeated it, a friend told me that she had heard a similar version at the Museo de Luján, in the Province of Buenos Aires. In 1806 and 1807 the British invaded Buenos Aires in what is known as the "Invasiones inglesas." Irish mercenaries were part of the invasion and, after been defeated in both circumstances, many stayed in the River Plate. One of them, a fellow called Jimmy Carrey, stopped in the countryside and little by little became a friend of the gauchos, who used to invite him to eat barbecue (what we call asado). He found it tasteless, and after several attempts, he created a rather hot sauce which was an instant success. Asked what the name of the sauce was, he answered that it had no name, that he had invented it. People started calling it "Jimmy Currey", a name that quickly developed into "Chimy Churry", the famous argentine sauce that you will always see in an asado party. I'm not able to prove the truthfulness of this story, but if it isn't true, it should be.

CAM: Thank you very much, Juan José, it's been a real pleasure to meet you!

Received: 14 November 2017 Accepted: 17 January 2018

Carolina P. Amador-Moreno is senior lecturer in English linguistics and Director of the Research Institute for Linguistics and Applied Languages at the University of Extremadura. Prior to joining the University of Extremadura, she held different teaching positions at the department of Languages and Cultural Studies at the University of Limerick, and was also lecturer in Hiberno-English in the English Department at University College Dublin. Her research interests centre on the English spoken in Ireland and include sociolinguistics, stylistics, discourse analysis, corpus linguistics and pragmatics. She is the author, among 
others, of An Introduction to Irish English. London: Equinox (2010); the co-edited volumes Writing Orality. Lewiston, New York: The Edwin Mellen Press (2009); Voice and Discourse in the Irish Context, London: Palgrave (2018); and Fictionalising Orality, a special issue of the journal Sociolinguistic Studies (2011). Other publications include articles in the journals Intercultural Pragmatics, English Language and Linguistics, Irish University Review, or the International Journal of English Studies. She is a member of the Centre for Applied Linguistics (CALS) and the Inter-Varietal Applied Corpus Studies Research Network (IVACS) at the University of Limerick.

camador@unex.es 